\title{
Project-based Learning Model, Learning Facilities, and Media Variations on Student Achievement in Social Studies
}

\author{
Nur imamah Utami, Ninik Indawati* \\ Master of Social Science Education Study Program \\ Universitas Kanjuruhan Malang \\ Malang, Indonesia \\ dini12345.dd@gmail.com, *ninikberty@unikama.ac.id
}

\begin{abstract}
Based on the result, most of the teachers still using the speech method so that the student less enthusiastic in the teaching-learning process of geography. The availability of learning facilities and then the media variation that is used by teachers yet not maximal so that the achievement still low. This study aims to analyze the effect of the project-based learning model, learning facility, and media variation toward the achievement of IPS students. This study is a quantitative study by using 89 students as saturation sampling. The instrument in collecting data are documentation and questionnaire. The technique of data analysis is multiple regression analysis, classic assumption test, and hypothesis test. (1) There is a significant effect between the combination of the PjBL learning model, facilitate learning, and media learning variation toward IPS students' achievement. (2) There is a significant effect between the PjBL learning model with IPS students' achievement. (3) There is a significant effect between facility learning with IPS student achievement. (4) There is a significant effect between media variation with IPS students' achievement. The teacher should develop some variation model in the teaching-learning process so that the student will be more active in it, one of example is by using project-based learning model, that parents and teachers should grow a motivation to the student to increase the facility learning in the school or the house. The aim is to make the student get the maximum achievement.
\end{abstract}

Keywords-Project-based learning model, facilitate learning, media variations IPS student achievement

\section{INTRODUCTION}

Project-based Learning (PjBL) Learning Model is a teaching strategy designed to educate group collaboration and interaction between students. Project-based learning $(\mathrm{PjBL})$ is a learning activity that uses a project/activity as a learning process to achieve attitudes, knowledge, and skills competencies. The emphasis of learning lies in the activities of students to produce products by applying skills to research, analyze, create, and present learning product based on real experiences. The product in question is the result of a project in the form of designs, schemes, papers, works of art, works of technology/ crafts, and others. This approach allows students to work independently or in groups to produce real products. Project-based Learning $(\mathrm{PjBL})$ is also a learning model that has an impact on student learning outcomes, where the learning process cannot be separated from the learning facilities and the variety of media required.

Based on previous research, there are similarities and differences in research with those to be carried out by researchers. The equation is to both test the influence of the independent variables on the dependent variable, while the difference is that there are different variables carried out by researchers that have not previously been done by other researchers.

The effectiveness of a learning model, of course, cannot only be based on the results of one study, but it requires a review of other similar studies. This review will be useful for researchers in conducting research related to the project-based learning model of learning facilities and media variations on learning outcomes. This review aims to analyze the effect of the project-based learning model of learning facilities and media variations on learning outcomes in high school students. The success of the effect of the project-based learning model of learning facilities and media variations on learning outcomes in high school students depends on the research design applied. By examining the project-based learning model of learning facilities and media variations on learning outcomes will produce the best information and can be scientifically accounted for so that it can be applied to other schools at the SMA level.

[1][2] One of the problems faced by the world of education is the weak learning process. In the learning process, children are less encouraged to develop thinking skills. The learning process in the classroom is directed only to memorize information, the child's brain is forced to remember and accumulate various memorized information to relate it to everyday life. Learning, in general, is "an activity carried out by the teacher so that student behavior changes for the better" 
[3][4]. The teacher tries to create an atmosphere and service for all the very diverse needs of students [3][5].

TABLE I. THE DAILY TEST SCORES OF GEOGRAPHY CLASS XI IPS IN THE ODD SEMESTER OF THE 2019/2020 ACADEMIC YEAR.

\begin{tabular}{|l|l|l|l|}
\hline Score & Total & Percentage & \multicolumn{1}{|c|}{ Information } \\
\hline$\geq 73$ & 36 & $40 \%$ & Complete \\
\hline$<73$ & 53 & $60 \%$ & Not Complete \\
\hline Total & 89 & \multicolumn{2}{|c|}{100} \\
\hline
\end{tabular}

Source: Documentation of geography class XI IPS subject teachers.

Learning with the project-based Learning (PjBL) Learning Model is a general term for a set of teaching strategies designed to educate group collaboration and interaction between students. The objectives of cooperative learning include at least three learning objectives, namely academic learning outcomes, acceptance of diversity, and the development of social skills [2][6]. "The project-based learning model (project-based learning) is an innovative learning that is centered on students (student-centered) and is allowed to work autonomously in constructing their learning" [1][7].

Project-based learning (PjBL) is a learning activity that uses a project or activity as a learning process to achieve competence in attitudes, knowledge, and skills. The emphasis of learning lies in the activities of students to produce products by applying skills to research, analyze, create, and present learning products based on real experiences. The product in question is the result of a project in the form of designs, schemes, written works, works of art, works of technology or crafts, and others. This approach allows students to work independently or in groups to produce tangible products.

According to the Education Media Standardization Guidebook for the Ministry of Education and Culture [8][9], what is meant by learning facilities are all the facilities needed in the teaching and learning process that is mobile or immobile so that the achievement of goals runs smoothly, regularly, effectively and efficiently, because of the availability of good learning facilities in school and at home can support student success in learning. In particular, the notion of media in the teaching and learning process tends to be interpreted as graphic, photographic, or electronic tools to capture, process, and reconstruct visual or verbal information [9][7]. The use of various learning media in teaching and learning activities can help attain learning objectives by the material to be conveyed to students. Based on this background, the researcher raised this problem by conducting a study entitled "The Influence of Project-based Learning (PjBL) Learning Models, Learning Facilities, and Variation of Learning Media on Social Studies Learning Outcomes of Class XI Students.

The objectives of this study were to: (1) analyze the effect of the PjBL learning model, learning facilities, and media variations together on learning outcomes, (2) analyze the effect of the PjBL learning model on social studies learning outcomes, (3) analyze the effect of learning facilities on learning outcomes. learning social studies, (4) analyzing the effect of media variations on social studies learning outcomes.

\section{METHODS}

This research is a quantitative study with an ex-post facto research design, often referred to as casual comparative research, because this research seeks to find information about the causal relationship of an event. The population and sample in this study were all students of class XI-IPS for the 2019/2020 academic year, totaling 89 students, the research sample was all the population, namely, 89 students were saturated samples.

While the instrument is in the form of a questionnaire and documentation, for documentation in the form of daily test scores for odd semester students of the 2019/2020 school year (table 1).

The data analysis technique uses multiple regression analysis, the classical assumption test, and hypothesis testing. Multiple regression analysis is used to determine the effect of the independent variables (the effect of the PjBL learning model, learning facilities, and media variations) on the dependent variable (learning outcomes). Classical assumptions used are the normality test, multicollinearity test, heteroscedasticity test, autocorrelation test, while the hypotheses used are: t-test, F-test, and determination (R2). The $\mathrm{t}$-test in this study was used to determine the significance level of the PjBL learning model (X1) on student learning outcomes (Y), and learning facilities (X2) on student learning outcomes (Y) and media variations (X3) on student learning outcomes (Y). The $\mathrm{F}$ test in this study was used to determine the significant level of the PjBL learning model (X1) on student learning outcomes (Y), learning facilities (X2) on student learning outcomes $(\mathrm{Y})$, and media variations $(\mathrm{X} 3)$ on student learning outcomes $(\mathrm{Y})$. determination $(\mathrm{R} 2)$ reflects how much the variance of the dependent variable $(\mathrm{Y})$ can be explained by the independent variable $(\mathrm{X})$.

\section{RESULTS}

\section{A. Description of research variables}

1) Learning outcomes: Average standard deviation from variable show in table 2 .

TABLE II. AVERAGE STANDARD DEVIATION

\begin{tabular}{|l|c|l|l|l|l|}
\hline \multicolumn{7}{|c|}{ Descriptive Statistics } \\
\hline & N & Minimum & Maximum & Mean & Std. Deviation \\
\hline X1Tot & 89 & 108 & 119 & 116.02 & 2.281 \\
\hline X2Tot & 89 & 47 & 66 & 58.10 & 3.662 \\
\hline X3Tot & 89 & 36 & 50 & 43.82 & 2.794 \\
\hline YTot & 89 & 60 & 90 & 79.06 & 6.863 \\
\hline Valid N (listwise) & 89 & \multicolumn{5}{|c|}{ Source: Results of data analysis using IMB SPSS Statistics 24 }
\end{tabular}




\section{2) PjBL learning model}

TABLE III. VARIABLE FREQUENCY DISTRIBUTION OF PPA LEARNING MODEL (X1)

\begin{tabular}{|l|l|l|l|l|l|}
\hline & SS & \multicolumn{1}{|c|}{ S } & \multicolumn{1}{c|}{ KS } & \multicolumn{1}{c|}{ TS } & STS \\
\hline Total & 1.794 & 336 & 2 & 2 & 2 \\
\hline Average & 83,94 & 15,67 & 0,091 & 0,091 & 0,091 \\
\hline \multicolumn{7}{|c|}{ Source: Results of data analysis using IMB SPSS Statistics 24}
\end{tabular}

\section{3) Learning facilities}

TABLE IV. VARIABLE FREQUENCY DISTRIBUTION OF LEARNING FACILITIES (X2)

\begin{tabular}{|l|l|l|l|l|l|}
\hline & \multicolumn{1}{|c|}{ SS } & \multicolumn{1}{c|}{ S } & \multicolumn{1}{c|}{ KS } & \multicolumn{1}{c|}{ TS } & \multicolumn{1}{c|}{ STS } \\
\hline Total & 541 & 405 & 259 & 29 & 12 \\
\hline Average & 43,35 & 32,46 & 20,74 & 2,31 & 0,95 \\
\hline
\end{tabular}

\section{4) Variations of media}

TABLE V. DistRIBUTION OF VARIABLE FREQUENCY OF MEDIA VARIATION (X3)

\begin{tabular}{|l|l|l|l|l|l|}
\hline & \multicolumn{1}{|c|}{ SS } & \multicolumn{1}{c|}{ S } & \multicolumn{1}{c|}{ KS } & \multicolumn{1}{c|}{ TS } & \multicolumn{1}{c|}{ STS } \\
\hline Total & 391 & 457 & 37 & 3 & 2 \\
\hline Average & 43,89 & 51,31 & 4,12 & 0,33 & 0,22 \\
\hline
\end{tabular}

Source: Results of data analysis using IMB SPSS Statistics 24

Table 5 above explains the frequency distribution of the Media Variation variable questionnaire scores obtained from 89 respondents. The results of the calculation of the average frequency score of each alternative answer with a number of 10 questions indicate that $43.89 \%$ of respondents answered strongly agree, $51.31 \%$ of respondents answered agree, $4.12 \%$ of respondents answered disagree, $0.33 \%$ of respondents answered no agree and $0.22 \%$ of respondents answered strongly disagree. So, it can be concluded that the agreed answers have a higher frequency. This shows the high level of media variation from the respondents.

\section{B. Classic Assumption Test}

The use of regression as an analysis model must fulfill several basic assumptions (Classical Assumptions), to obtain an unusual estimator from regression with ordinary least squares. In accordance with the statistical analysis techniques that will be used in this study, a classical assumption test is needed which consists of a normality test, a multicollinearity test, and a heteroscedasticity test. Based on the data obtained, it is calculated with the help of the SPSS 24 program, it can be presented as follows:

1) Normality test: Based on the Normal P-P Regression Standardized Residual study, it describes the distribution of data around the diagonal line and its distribution follows the direction of the diagonal line, which means that the regression model is used in this study fulfills the assumption of normality.

2) Multicollinearity test: To determine the presence or absence of multicollinearity, it is based on the calculation of the correlation coefficient between independent variables.
Multicollinearity test calculations were carried out with the help of the SPSS 24.0 computer. The guideline used for the multicollinearity test between variables is to look at the correlation value between independent variables, and in this test, it is expected that multicollinearity does not occur. If the VIF value in Collinearity Statistics between independent variables <10 (Edwards, 1979) means that there is no multicollinearity between free variables. On the other hand, if the VIF value in the correlation between independent variables is $>10$, there will be multicollinearity between the independent variables. Multicollinear assumption tests are analyzed using the computer help of the SPSS program version 24.0 [10][11].

3) Heteroscedasticity test: Heteroscedasticity test can be interpreted as the unequal variation of variables in all observations and the errors that occur show a systematic relationship according to the size of one or more independent variables, so that the error is not random (random). The residue on heteroscedasticity gets bigger the observation. Therefore, the greater the observation of the independent variables, the larger the residual average. Heteroscedasticity can occur due to the environmental dynamics of a variable that is difficult to identify when creating a regression model so that the assumption appears that regression should be free from heteroscedasticity.

4) Autocorrelation test: The results of Durbin Watson's calculation obtained a value greater than the value of du and smaller than the value of 4 -du $(1.721<2.001<2.279)$ so it can be stated that there is no autocorrelation.

\section{Hypothesis Testing}

Multiple Linear Regression Analysis (Multiple Regression). Multiple regression analysis is used to determine the effect of the independent variables (skills training methods, recitation, and learning facilities) on the dependent variable (learning outcomes).

1) F-test (ANOVA): Based on the results of the F-test, the value of Fcount $=1.094$ while the value of Ftable $=2.72$ then Fcount $=1.094\langle$ Ftable $=2.72$ or the value of Sig. 0.356 $>$ 0.05 , then Ho is rejected and $\mathrm{Ha}$ is accepted, meaning that the PjBL learning model, learning facilities, and media variations together (simultaneously) have a significant effect on social studies learning outcomes.

2) T-test: Based on the results of the t-test, it is known that the independent variable that has the most influence on learning outcomes is the learning facility, because the beta value (value of Standardized Coefficients) learning facilities has the greatest value so that it has a dominant influence on the dependent variable.

Analysis of the coefficient of determination (R2 test). Based on the results of the R2 test, the R Square number is 0.037 . This means that $3.7 \%$ of the social studies learning outcomes (Y) can be explained by the variable project-based learning model (X1), learning facilities (X2), and media 
variations (X3), and the rest $=96.3 \%$ is influenced by factors. Other factors, namely the economic condition of the family, the ability of teachers to teach, and interact in society.

\section{DISCUSSION}

The influence of the PjBL learning model, learning facilities, and media variations together on social studies learning outcomes. From the SPSS output that has been presented above, it is found that the results of multiple linear regression analysis ( $\mathrm{F}$ test / Simultaneous Test) produce an ANOVA model with a Fcount of 1.094 and a Sig. equal to 0.356 which reaches a significant value which proves that there is an influence between the three variables. And proven by the Linearity Test with the Deviation from Linearity Sig. is 0.61> 0.05 and the value of Fcount $<$ Ftable $(0.799<2)$. The normality test with the Kolmogorov-Smirnov Test obtained the KSZ value of 0.172 and Asymp.sig. 0.060> 0.05, it can be concluded that the data is normally distributed. Multicollinearity test shows a VIF value $<10$ which indicates that no multicollinearity causes the independent variables not to have a high linear correlation. So, it can be concluded that there is a significant linear relationship between the $\mathrm{PjBL}$ Learning Model variables, Learning Facilities, and Variation of Student Learning Media together on student learning outcomes.

In the current learning process, it is always required to be innovative so that students' interest in learning remains high. By combining using the PjBL learning model, the availability of good learning facilities, and the use of various media can be one unit that can have a very positive impact on students' interest in learning. So that this combination can create students who excel in knowledge and are good at application.

\section{A. The Influence of the PjBL Learning Model on Social Studies Learning Outcomes}

From the SPSS output that has been presented above, it is found that the results of linear regression analysis (t-test/ Individual test) produce an ANOVA model with a tcount of 2.663 and a Sig. 0.019 which indicates a significant value and proves that there is an influence between the $\mathrm{PjBL}$ learning model and learning outcomes. Multicollinearity test shows the value of VIFX11,115<10 which indicates that no multicollinearity causes the independent variables not to have a high linear correlation, which causes a significant linear relationship between the PjBL learning model variables and learning outcomes. Heteroscedasticity test using coefficients with the value of Sig. amounting to $0.950>0.05$, indicating that there are no symptoms of heteroscedasticity in the regression model because what is expected in this test does not occur symptoms of heteroscedasticity. From some of the tests above, it can be concluded that there is an influence between the PjBL Learning Model variables and the Learning Outcomes.

This influence is thought to be because the use of projectbased learning models can increase students' enthusiasm for learning so that it can improve student learning outcomes. This increase is due to the project-based learning model emphasizing a constructivist approach that allows students to build their knowledge through real activities so that they are more motivated to follow the learning process. This projectbased learning model is used to increase student interest in learning which can be seen from the attention of students who are focused on the ongoing learning process, increasing learning outcomes.

Table 3, show the results of the calculation of the average frequency score of each alternative answer with 24 questions showed that $83.94 \%$ of respondents answered strongly agree, $15.67 \%$ of respondents answered agreed, 0.091 respondents answered disagree, 0.091 respondents answered disagree and 0.091 respondents answered strongly disagree. So it can be concluded that the answers strongly agree to have a higher frequency. Results of research conducted by Insani [12] and Wina Triani [13]

This project-based learning (PjBL) learning model can be applied in learning to support effective learning so that students can easily grasp the explanation of the material presented and students build their knowledge by being actively involved in a complex learning process so that the knowledge they get will be stored properly because the "impression" that is obtained in the process of achieving a more meaningful knowledge, thus it can improve student learning outcomes.

The Effect of Learning Facilities on Social Studies Learning Outcomes From the output that has been presented above, the results of linear regression analysis (t-test/ individual test) produce an ANOVA model with a tcount of 2.708 and a Sig. of 0.081 indicates a significant value which proves that there is an influence between learning facilities and learning outcomes. Multicollinearity test shows a VIFX2 value of $1.040<10$ which indicates that no multicollinearity causes the independent variables not to have a high linear correlation and there is a significant linear relationship between the learning facility variables and learning outcomes. Heteroscedasticity test using coefficients with the value of Sig. amounting to $0.367>0.05$, indicating that there is no heteroscedasticity symptom in the regression model, because it is expected that in this test there will be no heteroscedasticity symptom. From some of the tests above, it can be concluded that there is an influence between the Learning Facilities variable and the Learning Outcomes.

The results of the calculation in table 4 of the average frequency score of each alternative answer with a number of 14 questions showed that $43.35 \%$ of respondents answered strongly agree, $32.46 \%$ of respondents answered agreed, $20.74 \%$ of respondents answered disagree, $2.31 \%$ of respondents answered no agree and $0.95 \%$ of respondents answered strongly disagree. So, it can be concluded that the answers strongly agree to have a higher frequency. This influence is thought to be due to the availability of learning facilities both at school and at home which can improve student learning outcomes. The results of this study are supported by previous research Anggraini [14] and Sarib [15] which states that the availability of learning facilities can improve student 
learning outcomes. This means that the completeness of learning equipment helps students so that learning objectives can run smoothly, regularly, effectively, and efficiently.

\section{B. The Influence of Media Variations on Social Studies Learning Outcomes}

From the results of the SPSS output that has been presented above, it is found that the results of linear regression analysis (t-test/individual test) produce an ANOVA model with a tcount of 2.688 and a Sig. 0.045 which indicates a significant value which proves that there is an influence between Media Variation and Learning Outcomes. The multicollinearity test shows a VIFX3 value of $1.097<10$ which indicates that no multicollinearity causes the independent variables to not have a high linear correlation and there is a significant linear relationship between variables. variety of media with learning outcomes. Heteroscedasticity test using coefficients with the value of Sig. amounting to $0.292>0.05$, indicating that there is no heteroscedasticity symptom in the regression model, because it is expected that in this test there will be no heteroscedasticity symptom. From some of the tests above, it can be concluded that there is an influence between the Variation of Media and Learning Outcomes.

This statement has been proven by the results of observations that show the frequency distribution of the variable media questionnaire scores obtained from 89 respondents. The results of the calculation of the average frequency score of each alternative answer with a number of 10 questions indicate that $43.89 \%$ of respondents answered strongly agree, $51.31 \%$ of respondents answered agree, $4.12 \%$ of respondents answered disagree, $0.33 \%$ of respondents answered no agree and $0.22 \%$ of respondents answered strongly disagree. So, it can be concluded that the agreed answers have a higher frequency. This shows the high level of media variation from the respondents.

This influence is thought to be due to the very creative use of media variations in the form of pictures, concept maps, posters, and so on, which can increase their enthusiasm and interest in learning geography subjects. Thus, it can improve student learning outcomes.

The results of this study are in line with previous research Anggraini [4] and Ramli [16] which states that the use of various media in learning activities can improve student learning outcomes. This means that the use of various media related to the material presented can provide an attraction for students to pay attention so that the lessons delivered are also easily absorbed by learning aids, also called teaching aids.

\section{CONCLUSION}

The results of the analysis can be concluded that there is a significant effect of the project-based learning model, learning facilities, and media variations both simultaneously and partially on social studies learning outcomes. This means that the higher the use of project-based learning models, learning facilities, and media variations, the higher the social studies learning outcomes will be.

\section{REFERENCES}

[1] P.P.S.K. Daryanto, "Yogyakarta: Penerbit Gava Media, 2014,” 2013.

[2] I.A.K. Sastrika, I.W. Sadia, and I.W. Muderawan, "Pengaruh Model Pembelajaran Berbasis Proyek terhadap Pemahaman Konsep Kimia dan Keterampilan Berfikir Kritis," e-Journal Progr. Pascasarj. Univ. Pendidik. Ganesha, 2014.

[3] Hamdani, Strategi Belajar Mengajar. Bandung: Pustaka Setia, 2011

[4] Muhsin, "Pengaruh Persepsi Tentang Pemanfaatan Variasi Media Dan Minat Belajar Terhadap Prestasi Belajar Mata Pelajaran Geografi Siswa Kelas Xi Madrasah Aliyah Sumber Bungur Kecamatan Pakong Kabupaten Pamekasan,” 2013.

[5] Agus Suprijono, Model Pembelajaran Inovatif. Surakarta: Yuma Presindo, 2010.

[6] Trianto, Model Pembelajaran Terpadu: Konsep, Strategi, dan Implementasinya dalam Kurikulum Tingkat Satuan Pendidikan (KTSP). Jakarta: Bumi Aksara, 2014.

[7] Azhar Arsyad, Media Pembelajaran.Cet. 17. Jakarta: PT. Raja Grafindo, 2014

[8] A.T. Prasasty, "Pengaruh disiplin dan motivasi belajar terhadap prestasi belajar matematika siswa kelas X SMK Bina Karya Insan Tangerang Selatan," Util. J. Ilm. Pendidik. Dan Ekon., vol. 1, no. 1, pp. 65-74, 2017

[9] A. Suharsimi, Prosedur penelitian suatu pendekatan praktik. 2013.

[10] F. Angraini, S. Nas, and S. Sumarno, "The effect of Learning Facility, Attention of Parents, and Learning Motivation on Student Achievement at State Senior High School 2 Kampar District," Int. J. Econ. Bus. Appl., vol. 3, no. 2, pp. 12-23.

[11] Jonathan Sarwono, PATH ANALYSIS. Teori, Aplikasi, Prosedu Analisis untuk Riset Skripsi, Tesis dan Disertasi (Menggunakan SPSS). Jakarta: PT. Elex Media Komputindo, 2012.

[12] G. Isnani, “The Influence of Classroom Climate, Learning Interest, Learning Discipline and Learning Motivation to Learning Outcomes on Productive Subjects," JPBM (Jurnal Pendidik. Bisnis dan Manajemen), vol. 3, no. 2, pp. 85-96, 2017.

[13] W. Triani, Z. Zulkarnain, and R. K. S. Utami, "Pengaruh model pembelajaran project based learning terhadap hasil belajar geografi," 2015

[14] E. Anggraini, "Pengaruh Pergaulan Teman Sebaya dan Motivasi Belajar Terhadap Hasil Belajar Ekonomi Siswa Kelas XI Ilmu Pengetahuan Sosial Sekolah Menengah Atas Negeri 1 Sukodono Tahun Ajaran 2013/2014." Universitas Muhammadiyah Surakarta, 2015.

[15] Sarib, "Pengaruh Aktivitas Dan Penyediaan Fasilitas Belajar Di Rumah Terhadap Prestasi Belajar Mata Pelajaran IPS Siswa Kelas V SD Negeri Bulmatet I Kecamatan Karangpenang Kabupaten Sampang,” 2014.

[16] R. Ramli, "The effect of learning motivation on student's productive competencies in vocational high school, West Sumatra," Int. J. Asian Soc. Sci., vol. 4, no. 6, pp. 722-732, 2014 